Ethos: Jurnal Penelitian dan Pengabdian kepada Masyarakat, Vol 8, No.2, Juni 2020: 229-236

\title{
Brand Awareness Pengembangan Produk Unggulan Daerah Tirta Polengan (AIr Mineral Rendah Kontaminasi)
}

\section{${ }^{1}$ Muhammad Muttaqien, ${ }^{2}$ Linda Kusumastuti Wardana, ${ }^{3}$ Diesy Nurfithriyani}

\author{
1,2,3 Universitas Muhammadiyah Yogyakarta, Yogyakarta, DI Yogyakarta, Indonesia \\ email: 'lindawardana@umy.ac.id
}

\begin{abstract}
Tirta Polengan is a brand of less-contaminated bottled water as a processed product sourced from a (pure) spring water located at the foot of Mount Merapi in Lembaran Village, Polengan Village, Srumbung District, Magelang District, Central Java. The technology used to manage the spring water that produce bottled water is Reverse Osmosis (RO). This research aims to develop and socialize product awareness or brand awareness of Tirta Polengan which conducted in several stages. The first stage is to socialize steps and activities that will be carried out; the next step is to create online media promotion and hold the training on how to use them; then to make marketing videos; continue with preparing the concept of marketing events; and lastly, to measure and analize the outcomes. Socialization and discussion with residents result in several decisions, namely the development of diversification product named Assyifa with the aim to provide health drinking water for consumers; the determination of the agreed production place in a shophouse near the swimming pool since it has spacious and strategic location close to the highway; designing Tirta Polengan bottle and glass packaging labels, as well as designing nameplate installed at 3 spots (in front of the production site, on the road to the production site, and at the production site).
\end{abstract}

Keywords: Tirta Polengan, Reverse Osmosis, Spring water, Less contaminated bottled water

\begin{abstract}
Abstrak. Tirta Polengan merupakan produk olahan dari sumber air murni kaki Gunung Merapi di Dusun Lembar, Desa Polengan, Kecamatan Srumbung, Kabupaten Magelang, Jawa Tengah menjadi air minum dalam kemasan rendah kontaminasi. Teknologi yang digunakan untuk mengolah sumber air tersebut menjadi air minum adalah Reverse Osmosis (RO). Pelaksanaan berupa pengenalan produk atau brand awareness. Tahap pertama berupa mensosialisasikan kegiatan yang akan dilakukan dan tahapan-tahapannya, pembuatan media promosi online dan pelatihan penggunaannya, pembuatan video marketing, penyusunan konsep event marketing, dan pengukuran hasil. Hasil sosialisasi dan diskusi bersama warga menetapkan pengembangan produk dengan nama Assyifa yang tujuannya agar air tersbut bisa memberi kesehatan bagi konsumen, penentuan tempat produksi yang disepakati di ruko dekat kolam renang dengan pertimbangan tempat yang luas dan stategis dekat dengan jalan raya, mendesain label kemasan botol dan gelas Tirta Polengan, serta mendesain papan nama dan dipasang di 3 titik, yaitu di depan tempat produksi, di jalan menuju tempat produksi, serta di tempat produksi.
\end{abstract}

Kata Kunci: Tirta Polengan, Reverse Osmosis, mata air pegunungan, air minum rendah kontaminasi

\section{Pendahuluan}

Desa Polengan merupakan salah satu desa di Kecamatan Srumbung Magelang Jawa Tengah dengan luas 4 $\mathrm{Km}^{2}$ dengan $60 \%$ merupakan lahan pertanian. Desa ini terletak di sebelah barat kaki Gunung Merapi yang mempunyai radius kurang lebih $11 \mathrm{Km}$ dari puncak gunung dan terdiri dari 7 dusun yaitu: Polengan, Kronggahan, Gejayan, Babadan, Larangan, Lembar, dan Gowok. Jumlah penduduk Desa 
Polengan adalah 2.156 jiwa dengan mayoritas mempunyai mata pencaharian menanam sawi, kacang panjang, pepaya, serta budidaya salak pondoh. Selain mempunyai produk unggulan sayur dan buah, hampir di setiap dusun yang berada di Desa Polengan mempunyai sumber mata air pegunungan murni. Mata air tersebut ditampung dalam sebuah bak besar di kaki Gunung Merapi, kemudian dialirkan menggunakan pipa ke pemukiman warga. Warga setempat memanfaatkan mata air tersebut untuk kebutuhan sehari-hari dan menyiram tanaman pertanian, belum ada yang memanfaatkan secara ekonomis. Sumber mata air di Desa Polengan mempunyai debit air yang stabil sepanjang tahun, bahkan ketika musim kemarau.

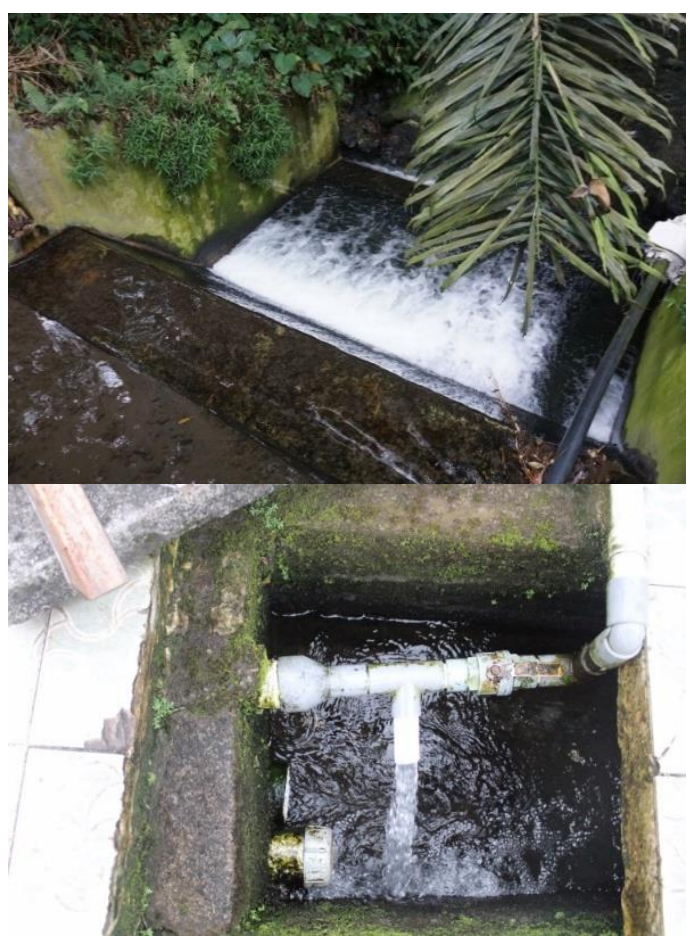

Gambar 1.Sumber Mata Air Dusun
Lembar

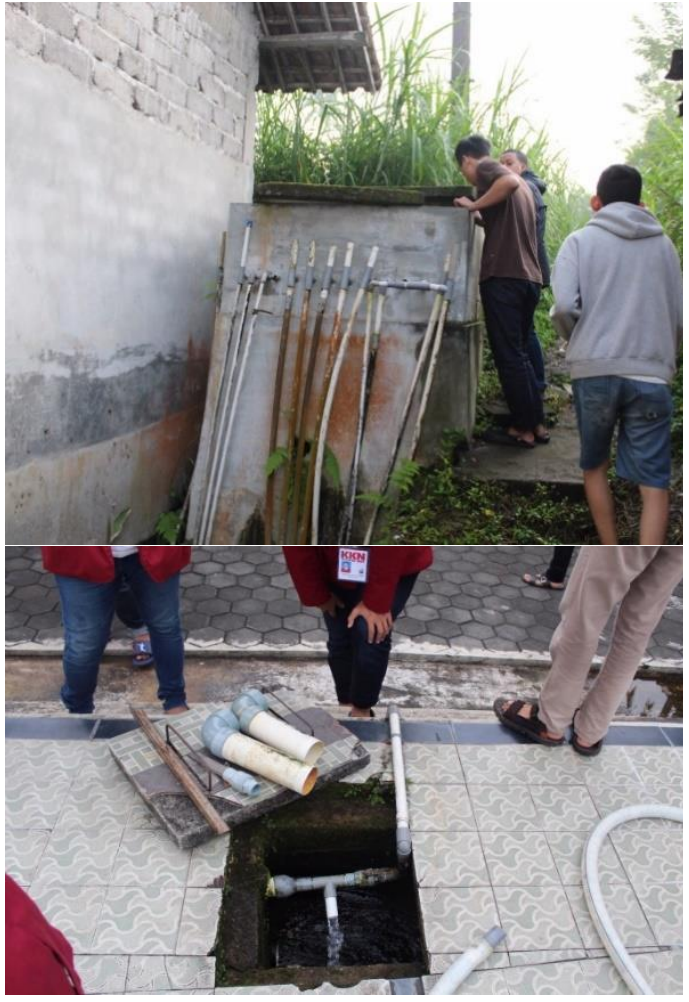

\section{Gambar 2. Aliran Pipa dari Penampungan Air ke Rumah Warga}

Berdasarkan uraian di atas, penulis bermaksud untuk memanfaatkan potensi sumber mata air Gunung Merapi tersebut menjadi air minum dalam kemasan rendah kontaminasi dengan menggunakan teknologi Reverse Osmosis (RO).

Adapun jenis air minum menurut Pasal 2 Kepmen Kesehatan RI Nomor 907/Menkes/SK/VII/2001 seperti air yang didistribusikan melalui pipa untuk keperluan rumah tangga; air yang didistribusikan melalui tangki air; air kemasan; dan air yang digunakan untuk produksi bahan makanan dan minuman yang disajikan kepada masyarakat harus memenuhi syarat kesehatan air minum. Persyaratan kesehatan air minum tersebut sebagaimana dimaksud pada Pasal 2 Ayat 1 Kepmen Kesehatan RI Nomor 907/Menkes/SK/VII/2001 adalah air 
yang bebas dari bakteriologis, kimiawi, radioaktif, dan fisik. Sumber mata air Dusun Lembar sudah diujicobakan di Laboratorium Kesehatan Masyarakat Dinas Kesehatan Pemerintah Kabupaten Magelang. Hasil uji laboratorium tersebut menunjukkan bahwa terdapat kandungan bakteri Escherichia Coli cukup rendah yaitu sebesar 4,0. Hasil tersebut di bawah nilai ambang batas maksimum yaitu 10. Selain itu, hasil uji laboratorium tersebut juga menunjukkan bahwa sumber air Dusun Lembar mengandung besi yang sangat kecil yaitu sebesar $0,028 \mathrm{mg} / \mathrm{L}$ dengan toleransi kandungan besi dalam air minum adalah sebesar $1 \mathrm{mg} / \mathrm{L}$. Berdasarkan hasil uji laboratorium tersebut dapat disimpulkan sumber air Dusun Lembar layak untuk dikonsumsi dan rendah kontaminasi.

Menurut Said Sutomo (2008) air merupakan salah satu kebutuhan yang sangat vital bagi manusia. Tidak semua air layak untuk dikonsumsi. Jika manusia mengkonsumsi air yang kurang baik kualitasnya, maka dapat menyebabkan berbagai penyakit (Sidharta, 2007). Hanya air tanah dari sumber mata air pegunungan yang dapat diolah menjadi air minum. Ada beberapa metode untuk mengolah dan pemurnian air menjadi air layak minum menurut Amrih (2007) yaitu; pertama, melalui proses pengendapan. Air yang diproses diendapkan dalam beberapa waktu, kemudian diambil beberapa centimeter dari permukaan. Kedua, penyaringan multimedia, yaitu dengan cara menyaring air dengan menggunakan berbagai media seperti batu, pasir, sabut kelapa dan kerikil. Ketiga, softener, proses ini dengan cara menggunakan pelunak seperti Anion Exchange dalam mengolah air. Tujuannya adalah mengurangi kadar ion mineral bebas dalam air. Keempat, penyaringan mikro, yaitu dengan menggunakan saringan yang seperseribu lebih kecil dari penyaringan multimedia. Kelima, penyaringan ultra, yaitu dengan menggunakan saringan seperseratur lebih kecil dari penyaringan mikro. Keenam, teknologi Reverse Osmosis (RO), yaitu penyaringan dengan menggunakan membaran semi permeable dan banyak digunakan di depot-depot air minum. Keunggulan teknologi ini adalah dapat mengolah air menjadi air layak minum rendah kontaminan. Oleh karena itu, proses produksi Tirta Polengan menggunakan teknologi RO.

Sebelumnya, penulis menginisiasi terbentuknya Kelompok Masyarakat Tirta Polengan melalui program KKN-PPM Universitas Muhammadiyah Yogyakarta (UMY). Melalui program tersebut, UMY memberikan alat penyulingan air Reverse Osmosis (RO) dan sealer cup serta sudah tercipta produk Tirta Polengan kemasan botol dan gelas sebagaimana tersaji pada Gambar 3.

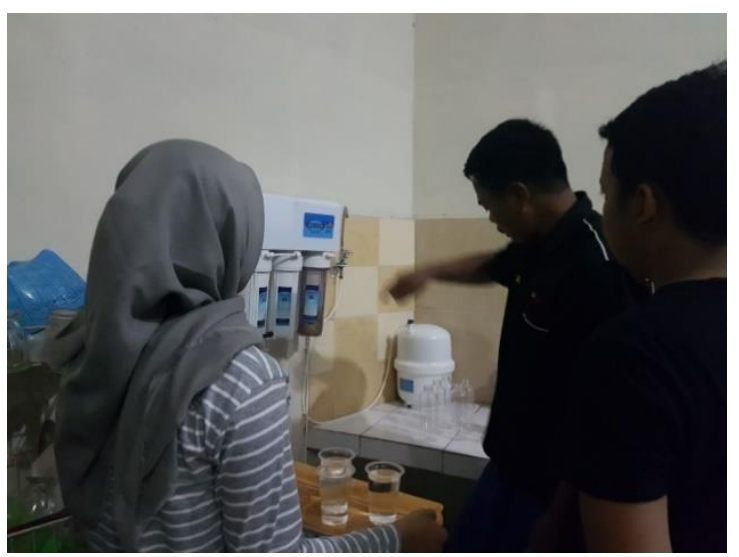




\section{Gambar 3. Proses Produksi dan}
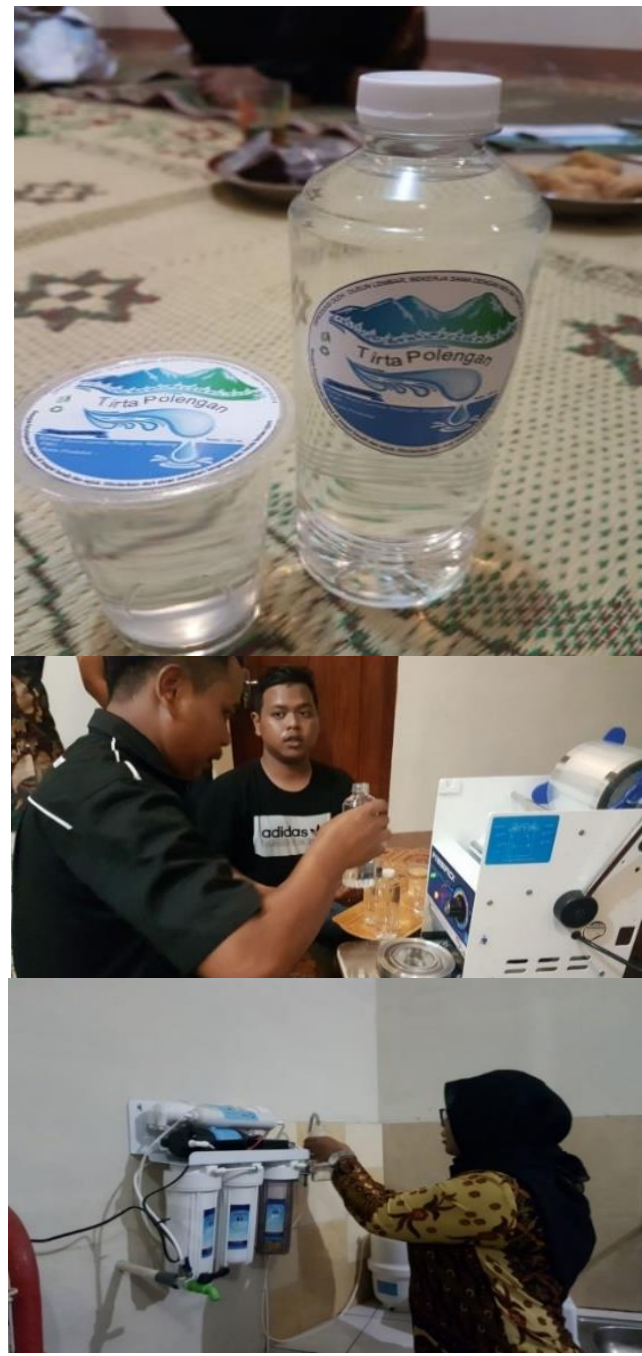

Pengemasan Tirta Polengan

Tim pengusul juga sudah melaksanakan beberapa pelatihan kepada mitra seperti pelatihan penentuan harga pokok produk, pelatihan pencatatan keuangan sederhana, dan pelatihan pemasaran yang berfokus pada pangsa pasar internal desa.

Tim pengusul melakukan monitoring pasca pengabdian, yaitu rentang 2 bulan program KKN PPM internal UMY berakhir. Hasil monitoring pasca pengabdian menunjukkan bahwa kelompok usaha Tirta Polengan masih aktif berproduksi dan produk Tirta Polengan sudah diterima di masyarakat internal digunakan untuk kegiatan desa seperti rapat atau hajatan. Namun, ada beberapa permasalahan yang dihadapi mitra yaitu, Pertama, Kelompok Usaha Tirta Polengan sudah tidak mampu memenuhi permintaan pasar karena keterbatasan kapasitas alat produksi sehingga banyak permintaan yang tidak dapat terpenuhi. Kedua, saat ini produk hanya dikenal di masyarakat internal desa, pasar potensial di luar desa belum terjangkau sehingga membutuhkan strategi pemasaran yang lebih kuat dan lingkup yang lebih luas melalui Brand Awarness.

\section{Metode}

\section{Brand Awareness}

Kegiatan ini dilaksanakan dengan tujuan untuk memperkenalkan produk Tirta Polengan ke lingkup pasar yang lebih luas terutama adalah luar masyarakat Desa Polengan. Tahap kegiatannya meliputi:

1. Sosialisasi kegiatan yang akan dilakukan

2. Pada tahap ini tim pengabdian menginformasikan kepada pengelola Bumdes Polengan tentang kegiatan yang akan dilaksanakan, tujuan dari kegiatan tersebut, kemudian tahap-tahapan kegiatan yang akan dilakukan.

3. Pembuatan media promosi online Facebook, Instagram, Website, Youtube.

4. Pelatihan penggunaan media promosi online

5. Pembuatan video marketing 
6. Penyusunan konsep event marketing

7. Pengukuran hasil/responsi masyarakat terhadap produk

Pengukuran dilaksanakan setelah peluncuran produk dengan kemasan baru ke masyarakat kemudian memberikan contoh ke masyarakat dan meminta tanggapan akan produk Tirta Polengan.

\section{Hasil dan Pembahasan}

Tim pengabdian telah melakukan beberapa rangkaian kegiatan sesuai dengan metode pelaksanaan yang sudah ditentukan sebelumnya. Adapun hasil yang diperoleh adalah sebagai berikut:

1. Observasi lanjutan

Pada tahap ini peneliti melakukan observasi ke tempat produksi Tirta Polengan sebelumnya dan bertemu dengan perangkat desa dan pengelola Bumdes Polengan untuk mencari tempat potensial untuk produksi Tirta Polengan dalam jumlah besar.
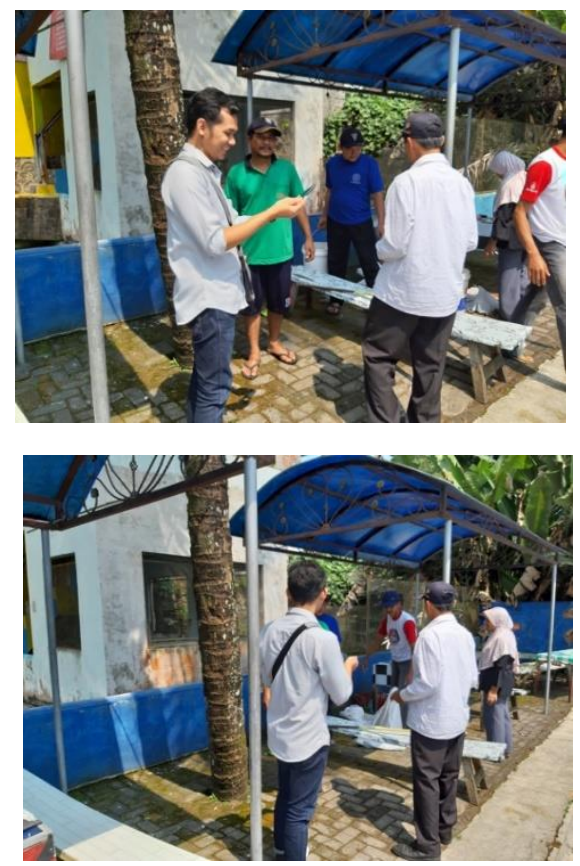

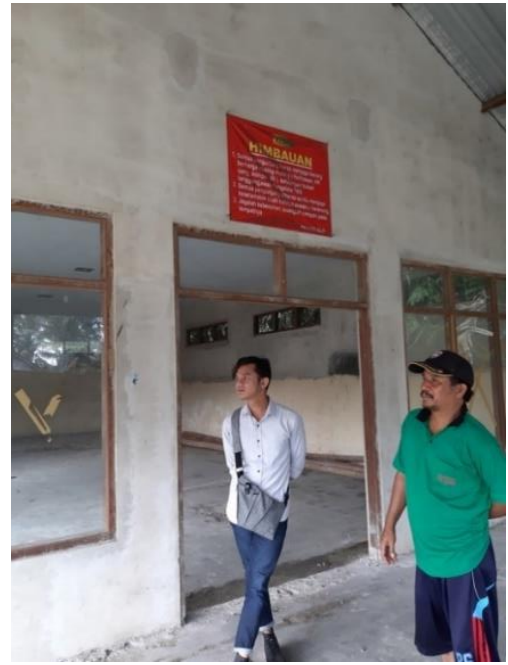

Gambar 4 Observasi Lanjutan Penentuan Lokasi

2. Sosialisasi Program dan Diskusi dengan Pengelola Bumdes Polengan

Pada tahap ini tim pengabdian menjelaskan program yang akan dilaksanakan kepada mitra. Kemudian, penjelasan dan diskusi menghasilkan beberapa keputusan yaitu:

1. Adanya pengembangan diversifikasi produk Tirta Polengan dengan merk Assysifa. Assyifa nantinya merupakan produk Tirta Polengan yang akan diberi doa dari pesantren dengan harapan dapat memberikan kesehatan bagi konsumen.

2. Tempat produksi Tirta Polengan akan dilaksanakan di ruko dekat kolam renang dengan pertimbangan tempat yang luas dan strategis dekat dengan jalan raya.

3. Menentukan garis besar hal-hal yang akan dicantumkan dalam desain label dan papan nama.

4. d. Membagi job description pengurus Tirta Polengan. 


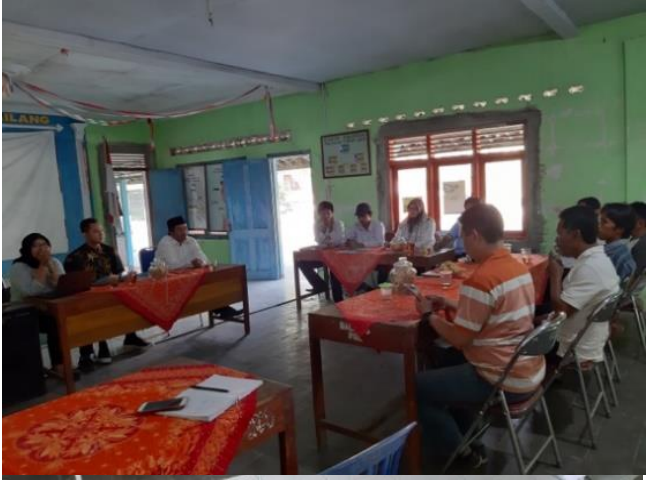

Gambar 5 Sosialisasi Program dan Diskusi

3. Mendesain label kemasan botol dan gelas

Desain label kemasan botol dan gelas disesuaikan dengan permintaan dari pengelola Tirta Polengan. Desain label kemasan botol dan gelas tersaji pada Gambar 6.
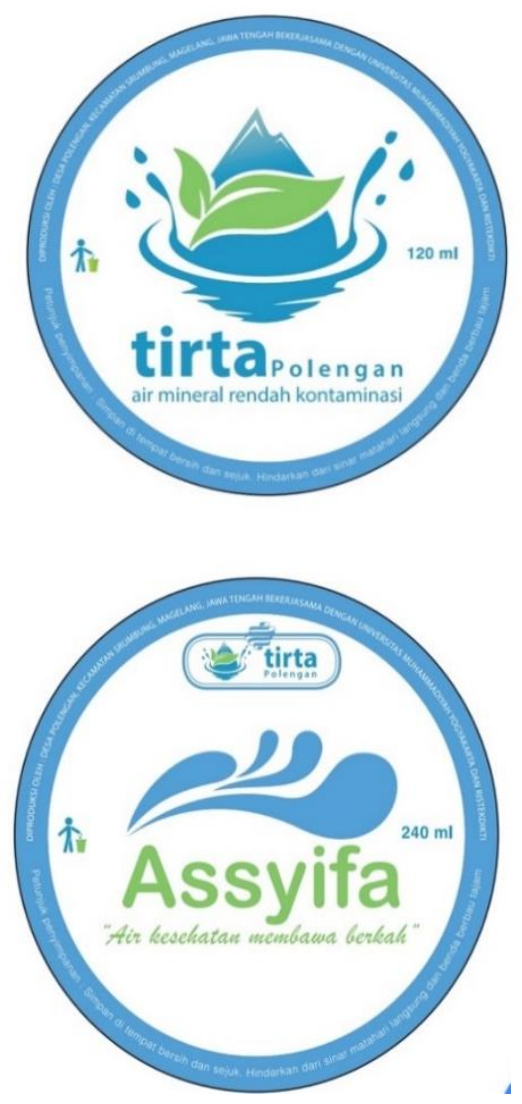

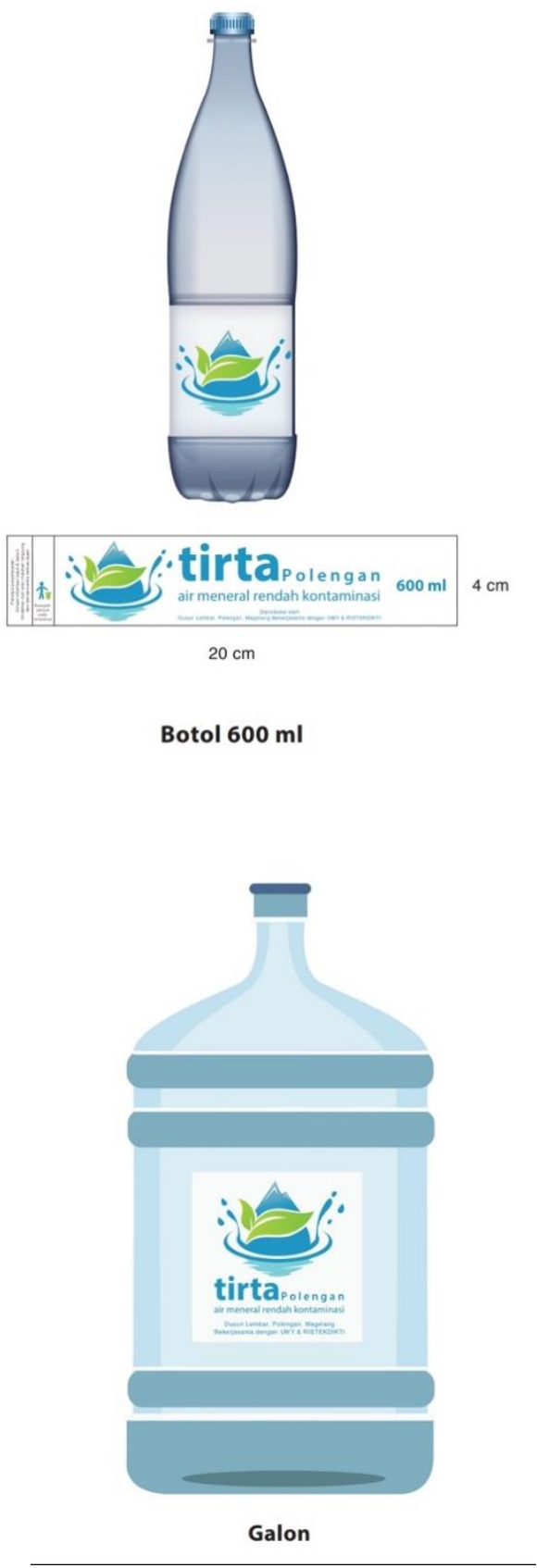

Gambar 6 Desain Label Kemasan Gelas, Botol, dan Galon

4. Mendesain papan nama

Desain label papan nama disesuaikan dengan permintaan dari pengelola Tirta Polengan. Desain label papan nama tersaji pada Gambar 7. 


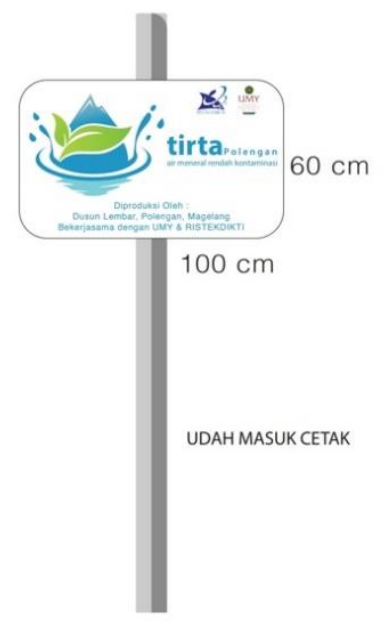

Papan nama

\section{Gambar 7 Desain Papan Nama}

5. Pelatihan branding produk Pelatihan branding produk Tirta Polengan ditujukan kepada pengelola Bumdes Polengan dengan materi pentingnya melakukan branding untuk sebuah usaha kemudian bagaimana cara mempromosikannya. Pelatihan ini dihadiri oleh 10 orang pengelola.
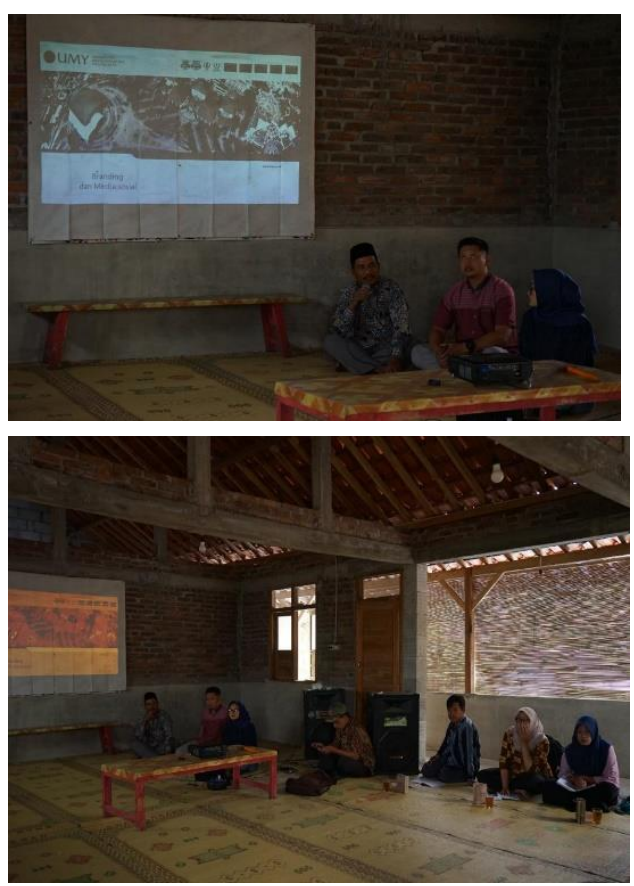

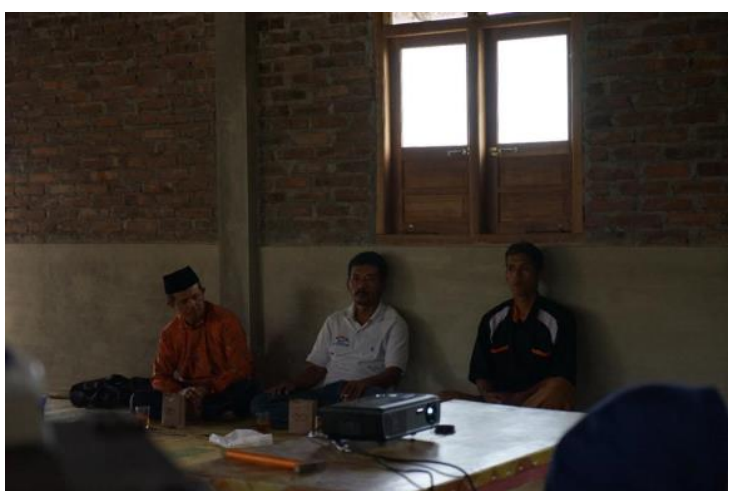

6. Pemasangan papan nama

Papan nama dipasang di 3 titik, yaitu di depan tempat produksi, di jalan menuju tempat produksi, serta di tempat produksi.

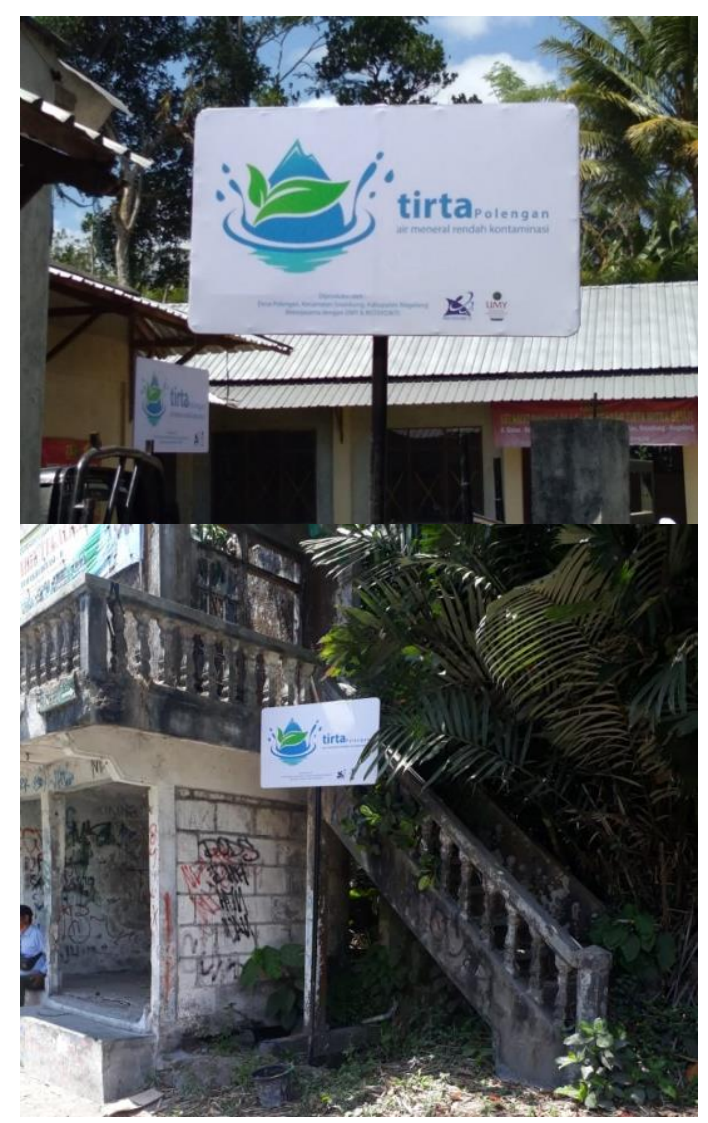




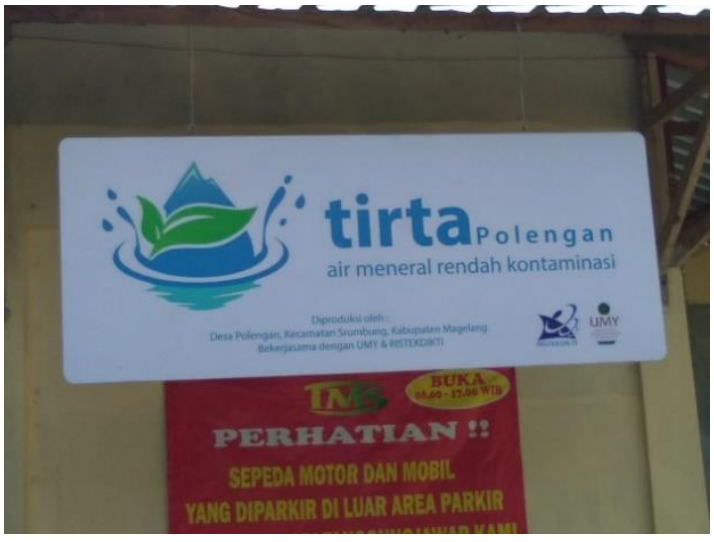

7. Persiapan Tempat Produksi dan Pengiriman alat

Alat yang sudah dipesan yaitu alat untuk memproduksi air dengan volume yang lebih banyak sudah dikirimkan ke lokasi produksi. Tetapi, alat belum bisa diinstalasi karena ada beberapa tempat yang perlu diperbaiki oleh pihak desa.

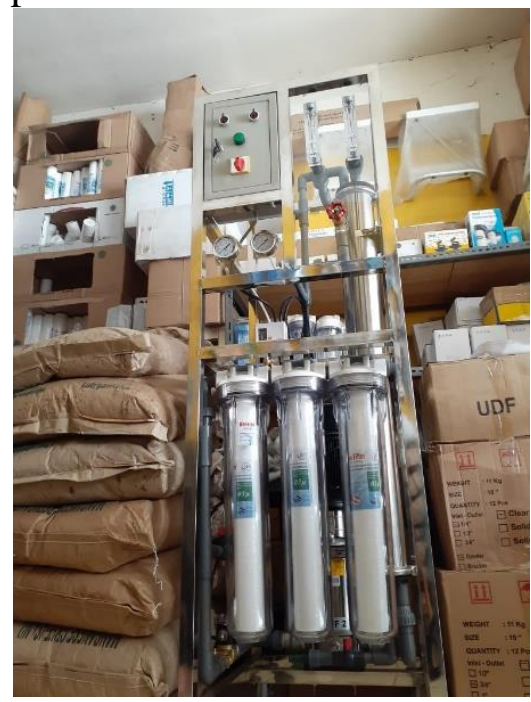

\section{Kesimpulan dan Saran}

Program kemitraan masyarakat melalui pendampingan pengolahan sumber air Dusun Lembar, Desa Polengan, Kecamatan Srumbung, Magelang dapat memberikan alternatif pemecahan masalah yang terjadi di masyarakat adalah masyarakat mempunyai gambaran untuk membangun brand awareness atas produk untuk memperluas pangsa pasar dan mendapatkan pasar potensial yang belum tersentuh.

\section{DAFTAR PUSTAKA}

Keputusan Menteri Kesehatan Republik Indonesia Nomor 907/Menkes/SK/VII/2002 Tentang Syarat-Syarat dan Pengawasan Kualitas Air Minum Menteri Kesehatan Republik Indonesia.

Peraturan Menteri Kesehatan RI Nomor 416/MENKES/Per/IX/1990 tentang air yang digunakan untuk keperluan sehari-hari yang kualitasnya memenuhi syarat kesehatan dan dapat diminum.

Said Sutomo. 2008. Masyarakat Jatim Harus Waspada Mengkonsumsi Air Minum.

www.seputarair.wordpress.com., diakses tanggal 15 Oktober 2019. 